http://dx.doi.org/10.1590/1678-4162-8974

Arq. Bras. Med. Vet. Zootec., v.69, n.2, p.391-397, 2017

\title{
Caprine lentivirus in sheep milk and semen
}

\author{
[Lentivírus caprino em leite e sêmen de ovinos] \\ C.C.V. Lima ${ }^{1}$, M.C.C. Ayres ${ }^{1}$, R.R. Pinheiro ${ }^{2}$, J.N. Costa ${ }^{3}$, A. Andrioli ${ }^{2}$, T.S. Souza ${ }^{3}$, \\ D.A.A. Azevedo ${ }^{4}$,V.W.S. Santos ${ }^{5}$, J.F. Araújo ${ }^{6}$, A.L.M. Sousa ${ }^{6}$, R.M. Peixoto ${ }^{4}$, \\ E.M. Damasceno ${ }^{6}$, A.O. Costa Neto \\ ${ }^{1}$ Universidade Federal da Bahia, Salvador, BA \\ ${ }^{2}$ Empresa Brasileira de Pesquisa Agropecuária, Sobral, CE \\ ${ }^{3}$ Universidade Federal do Recôncavo da Bahia, Cruz das Almas, BA \\ ${ }^{4}$ Universidade Estadual do Ceará, Fortaleza, CE \\ ${ }^{5}$ Universidade Federal Rural do Semiárido, Mossoró, RN \\ ${ }^{6}$ Universidade Estadual do Vale do Acaraú, Sobral, CE \\ ${ }^{7}$ Universidade Estadual de Santana, Feira de Santana, BA
}

\begin{abstract}
With the objective of detecting the presence of caprine lentivirus (CLV) in ewe milk and in ram semen, ten matrixes and four reproducers experimentally infected with CLV were used. Samples of ewe milk were collected during the four months of lactation, five collections per animal, totaling 50 samples. Regarding the rams, eight semen collections were made per animal, during one year of experimentation, totaling 32 samples. The milk and semen samples were submitted to DNA extraction and the nested polymerase chain reaction test (nPCR) to detect CLV proviral DNA. Eight (16\%) of the milk samples were positive in nPCR originating from two ewes. Only one $(3.12 \%)$ semen sample was positive. The amplification products were sequenced, and were confirmed to be a CLV genomic sequence. Thus, the presence of CLV proviral DNA in sheep milk and semen was demonstrated, confirming the feasibility of infection between species, and alerting to the risk of spreading infections.
\end{abstract}

Keywords: lentiviruses, transmission, cross infection

\section{RESUMO}

Com o objetivo de detectar a presença do lentivírus caprino (LVC) no leite de ovelhas e no sêmen de carneiros, utilizaram-se 10 matrizes e quatro reprodutores infectados experimentalmente com o LVC. Foram coletadas amostras de leite das ovelhas durante os quatro meses de lactação, ocorrendo cinco coletas por animal, totalizando 50 amostras. Quanto aos carneiros, realizaram-se oito coletas de sêmen por animal, durante um ano de experimentação, totalizando 32 amostras. As amostras de leite e de sêmen foram submetidas à extração de DNA e à prova de reação em cadeia da polimerase do tipo nested (nPCR) visando à detecção de DNA proviral do LVC. Oito (16\%) amostras de leite foram positivas na nPCR oriundas de duas ovelhas. Apenas uma (3,12\%) amostra de sêmen apresentou positividade. Produtos da amplificação foram sequenciados, confirmando-se tratar de sequência genômica do LVC. Dessa forma, demonstrou-se a presença do DNA proviral do LVC em leite e sêmen de ovinos, confirmando a viabilidade da infecção entre espécies e, assim, alertando sobre o risco de que a infecção seja disseminada.

Palavras-chave: lentiviroses, transmissão, infecção cruzada

Recebido em 12 de maio de 2016

Aceito em 28 de setembro de 2016

E-mail:carlacvlima@gmail.com

Apoio financeiro: Coordenação de aperfeiçoamento de Pessoal de Nível Superior (Capes). Fundação de Amparo à Pesquisa do Estado da Bahia (Fapesb) e Conselho Nacional de Desenvolvimento Científico e Tecnológico (CNPq) 


\section{INTRODUCTION}

Caprine arthritis encephalitis (CAE) and ovine maedi-visna (MV) are diseases caused by small ruminant lentiviruses (SRLV), characterized by chronic evolution and progressive worsening until death (Blacklaws, 2012). Different clinical manifestations are known, the main ones being arthritis, pneumonia, encephalitis and mastitis, besides progressive weight loss (Pasick, 1998; Souza et al., 2015).

The most important transmission routes are by ingesting contaminated milk and colostrum, and by contact with secretions containing the virus, such as those from the respiratory and reproductive tract. Thus, transmission may happen vertically, between the infected matrix and its offspring (Alvarez et al., 2005); horizontally, by direct contact between infected and susceptible animals (Villoria et al., 2013), and in iatrogenic way, with emphasis on artificial feeding and use of semen in reproduction techniques (Alvarez et al., 2006; Andrioli et al., 2006; Souza et al., 2013).

The etiologic agents of CAE and MV were considered to be species-specific for many years. However, genomic analyzes of SRLV pointed to the occurrence of heterogeneous strains, evolved from viral prototypes of CAE and $\mathrm{MV}$, able to infect both goats and sheep (Shah et al., 2004).

In this sense, the transmission of caprine lentivirus to sheep has already been proved (Souza et al., 2015), but it is not yet clear whether animals infected with heterologous strains can transmit the infection. Thus, the objective of the present experiment was to detect the presence of caprine lentivirus proviral DNA in the milk and semen of experimentally infected sheep.

\section{MATERIAL AND METHODS}

The experiment was performed in the National Center of Goat and Sheep Research, belonging to the Brazilian Enterprize for Agricultural Research ("Empresa Brasileira de Pesquisa Agropecuária (Embrapa Caprinos e Ovinos),”) in the municipality of Sobral (CE), Brazil, under aproval from the Committee of Ethics on Animal Use from the Vale de Acaraú State University
("Universidade Estadual do Vale do Acaraú") (number 001/2012).

In order to detect caprine lentivirus (CLV) in sheep milk and semen, two experimental groups of crossbred Morada and Santa Inês one year old animals were kept isolated in experimental stalls. The first group consisted of 10 ewes and the second of four rams. Both the ewes and rams were infected with CLV at birth, by feeding on colostrum and milk from infected goats. Infection by CLV was confirmed by nested polymerase chain reaction tests (nPCR) at seven days of life and the animals were clinically evaluated throughout the experiment.

In the group of ewes, milk samples were collected at $30,60,75,90$ and 120 days of lactation in sterile $15 \mathrm{~mL}$ falcon vials after cleaning the teats using cheescloth and 70\% alcohol. The ewes were milked delicately until $15 \mathrm{~mL}$ milk was obtained from each teat.

The milk samples were centrifuged at $3,000 \mathrm{~g}$ for 15 minutes and washed five times with phosphate-buffered saline solution (PBS) to obtain the cell pap, based on the methodology described by Sardi et al. (2012). DNA was extracted according to Grimberg et al. (1989), using Lithium chloride and proteinase $\mathrm{K}$. After extraction, samples were stored at $-20^{\circ} \mathrm{C}$, until the nPCR technique was performed.

In the group of rams, eight semen collections were made per animal, during one year of experimentation. Semen was collected using an artificial vagina, using an ewe in rut as a dummy.

For gel filtration in a Sephacryl S-40 column, $100 \mu \mathrm{L}$ of fresh semen was used, according to a method by Santurde et al. (1996), to remove impurites. Then, $3 \mu \mathrm{L}$ of each filtrate was transfered to steryle microtubes to extract the DNA, using $200 \mu \mathrm{L}$ Chelex 100 solution at $5 \%$, $2 \mu \mathrm{L}$ proteinase $\mathrm{K}(10 \mu \mathrm{g} / \mu \mathrm{L})$ and $7 \mu \mathrm{L}$ Dithiothreitol at $1 \mathrm{M}$, incubated in a water bath at $56^{\circ} \mathrm{C}$, for 60 minutes. After this stage, samples were homogeneized for 10 seconds and heated in a boiling water bath $\left(100^{\circ} \mathrm{C}\right)$ for eight minutes to inactivate proteinase $\mathrm{K}$. Later the filtrate was centrifuged for three minutes at $13,000 \mathrm{G}$ and stored in a freezer at $-20^{\circ} \mathrm{C}$ until the nPCR test was performed. 
DNA samples extracted from milk and semen were submited to the nPCR technique, according to Barlough et al. (1994), modified by Andrioli et al. (2006). The reaction consisted of a total volume of $50 \mu \mathrm{L}$, containing buffer $(10 \mathrm{mM}$ tris$\mathrm{HCl}, 50 \mathrm{mM} \mathrm{KCl}$ and $\left.1.5 \mathrm{mM} \mathrm{MgCl}_{2}\right), 100 \mu \mathrm{M}$ each dNTP, 20pmol each oligonucleotide primer, $2 \mathrm{U}$ Taq polymerase; $3 \mu \mathrm{L}$ sample in the first stage and $1 \mu \mathrm{L}$ of its product in the second stage, completed to the final volume with sterile water. In paralel with the tested samples, a negative (sterile water) and a positive sample (material extracted from cultured synovial membrane infected with lentivirus strain B1, circulating in the experimental flock of goats infected with lentivirus at Embrapa National Research Center for Goats and Sheep) were used as control.

Two pairs of oligonucleotide primers were used in the reaction, obtained from the sequence from the gag gene region, from the standard CAEV-Cork strain (Saltarelli et al., 1990), namely P1 primers (5'CAAGCAGCAGGAGGGAGAAGCTG-3') and P2 primers (5'-TCCTACCCCCATAATTTGATCCAC3 ') used to obtain a target sequence of $297 \mathrm{pb}$ and P3 primers (5'-GTTCCAGC AACTGCAAACAGTAGCAATG-3') and P4 (5'ACCTTTCTGCTTCTTCATTTAATTTCCC$\left.3^{\prime}\right)$, to obtain a target fragment of $187 \mathrm{pb}$ (Rimstad et al., 1993).

Amplification reactions were performed in a thermocycler (Programmable Thermal Controller, PTC-100, MJ Research, Inc.), consisting of an inicial cycle at $94^{\circ} \mathrm{C}$ for five minutes; followed by 35 cycles of one minute at $94^{\circ} \mathrm{C}$, one minute at $56^{\circ} \mathrm{C}$ and 45 seconds at $72^{\circ} \mathrm{C}$; final extension at $72^{\circ} \mathrm{C}$ for seven minutes. The amplified samples and positive and negative controls, along with 100 bp DNA ladder ${ }^{\circledR}$ marker, were submited to agarose gel electrophoresis at $2 \%$ in TBE (Tris, borate and EDTA $0.1 \mathrm{X}$ ), stained with ethidium bromide and visualized in an ultraviolet transilluminator (Andrioli et al., 2006).

The samples positive in nPCR were sequenced on the Applied Biosystems $\AA 3500$ Genetic Analyzer platform. These sequencies were aligned using Clustal W (Thompson et al., 1994), with the BioEdit Sequence Alignment Editor ${ }^{\circledR}$ program (Hall, 1999) and compared with sequencies from standard CAEV Cork and MVVK1514 strains, available in GenBank under numbers M33677 and M60610, respectivelly, along with the sequence obtained from the strain circulating in Embrapa National Research Center for Goats and Sheep (BR/CNPC-G1), classified as subtype B1.

\section{RESULTS AND DISCUSSION}

CLV proviral DNA was detected in the milk of ewes by the nPCR technique in eight out of the 50 analyzed samples (Tab. 1). These positive samples belonged to two out of the ten ewes used.

Table 1. Results of nested PCR in milk samples from ten ewes experimentally infected with caprine lentivirus, collected from 30 until 120 days of lactation

\begin{tabular}{ccccccccccc}
\hline \multirow{2}{*}{ Period } & \multicolumn{10}{c}{ Ewes } \\
\cline { 2 - 11 } & 1 & 2 & 3 & 4 & 5 & 6 & 7 & 8 & 9 & - \\
\hline 30 days & - & - & - & + & - & - & + & - & - & - \\
\hline 60 days & - & - & - & + & - & - & + & - & - & - \\
\hline 75 days & - & - & - & + & - & - & + & - & - & - \\
\hline 90 days & - & - & - & - & - & - & + & - & - & - \\
\hline 120 days & - & - & - & - & - & - & + & - & - & - \\
\hline
\end{tabular}

(-): Negative; (+): Positive.

The capacity of nPCR for detecting proviral DNA in milk was verified in other studies (Gregory et al., 2011; Sardi et al., 2012); but they worked with goats and thus there was low detection in the face of the infection, which may be justified by the possible small number of copies of the viral genome present in the milk cells since the viral load varies (Barquero et al., 2013).

In this experiment, proviral DNA detection by nPCR was $16 \%$ and this may be due to the low viral load. This fact is associated to the variability in the milk cellular composition, 
mainly due to monocytes that shelter proviral DNA, that may be caused by several factors, influencing the diagnostic capacity of nPCR for CLV in milk (Ravazzolo et al., 2006; Gomes et al., 2010; Barbosa et al., 2012; Blacklaws, 2012).

The detection of CLV proviral DNA in ewe milk proved the presence of infected cells, but not necessarily the presence of the viral particle in the milk, suggesting the mammary gland as a potential route for eliminating CLV (Ravazzolo et al., 2006; Gregory et al., 2009).

It has already been proved that cells carrying proviral DNA are able to transmit the virus (Herrmann-Hoesing et al., 2007). Thus, the milk of ewes infected with CLV proviral DNA must be considered among the risk factors for controlling the disease.

It is noteworthy that there was no clinical manifestation of the disease in the ewes, the udders remained healthy throughout the experimental period, discarding the possibility of indurative mastitis, which is in agreement with the low viral replication in the mammary gland, which reduced the occurrence of injuries (Gregory et al., 2009). Clinically healthy animals may have a lower viral load (Ravazzolo et al., 2006), and this possibly justifies the discreet detection of positivity in nPCR.

The presence of caprine lentivirus proviral DNA was also observed in a sample of sheep semen, from the 32 evaluated sheep (Tab. 2).

Table 2. Results of nested PCR in samples from four rams experimentally infected with caprine lentivirus, collected between April, 2013 and April, 2014.

\begin{tabular}{ccccccccc}
\hline \multicolumn{7}{c}{ Samples } \\
\hline Rams & 1 & 2 & 3 & 4 & 5 & 6 & 7 & 8 \\
\hline 11 & - & - & - & - & - & - & - \\
\hline 12 & - & - & - & - & - & - & - \\
\hline 13 & - & - & - & - & - & - \\
\hline 14 & - & - & - & - & - & - \\
\hline
\end{tabular}

(-): Negative; (+): Positive.

The presence of CLV proviral DNA has already been detected in naturally and experimentally infected male goats. Paula et al. (2009) verified intermittence in positivity to nPCR when conducting studies with goats infected with the same strain as used in the presentexperiment.

The physical examination of the ewes and rams did not indicate any clinical alteration of infection by lentivirus. This absence of symptoms has been reported in other studies (Cavalcante et al., 2013; Souza et al., 2015), and may be associated with factors such as the pathogenicity of the viral strain for sheep, since it was circulating only in goats and, demonstrating symptoms in them. Possibly it did not establish a natural mechanism of adaptation to the ovine species, corroborating with the absence of clinical manifestation (Gregory et al., 2011; Rachid et al., 2013).

It is important to highlight that some viral quasispecies are proven to be more adapted to goats and others to sheep, and that the species interaction is different, which must be considered when interpreting results (Shah et al., 2004; Souza et al., 2015; Rachid et al., 2013).

It is also important to highlight the possibility of the virus entering a state of quiescence, when its genetic material remains integrated to the nuclear DNA, but without being activated, or in an intracellular environment, but not integrated (Cavalcante et al., 2013), justifying the absence of replication that would stimulate the clinical manifestation.

Regarding the discreet detection of positivity in nPCR, this may be due to the low viral replication in those infection sites, and therefore the capacity to detect genetic material in the tissues (Barquero et al., 2013), although breast is a preferred site for lentivirus replication in small ruminants (Ravazzolo et al., 2006; Gregory et al., 2011).

It is also important to consider that regarding the detection of genetic material, small ruminant 
lentivirus have the characteristic named intermittence, alternating between positivity and negativity, depending on the presence of infected cells in the evaluated sample (Alvarez et al., 2005; Paula et al., 2009).

Regarding the genetic sequences obtained by sequencing samples positive in nPCR (Figure 1), it was verified that they are sequences of the caprine lentivirus gag gene, with some changes occurring in nucleotides in the studied fragment (Feitosa et al., 2010; Souza et al., 2015).

Regarding the homology of the sequences, it was verified that sequences of milk from ewes 04 and
07 had $98 \%$ and $97 \%$ homology with CLV Cork, and $90 \%$ and $88 \%$ with strain MVV K1514, respectively. The sequence obtained from semen demonstrated 100\% homology with CLV Cork and $90 \%$ with MVV K1514. This may be explained by the selection imposed by the milk and semen compartmentalization over the caprine lentivirus (CLV) population. The compartmentalization of small ruminant lentivirus (SRLV) quasispecies is determined as the genetic distinction of SRLV isolates in tissues from different animals, corresponding to viral sub-populations in the same individual (Ramirez et al., 2012).

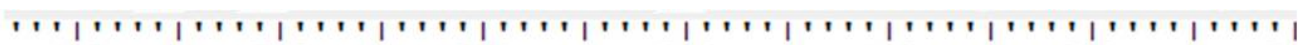

$\begin{array}{llllll}490 & 500 & 510 & 520 & 530 & 540\end{array}$
Semen/Ram 13TrCCAGCAACTGCAAACAGTAGCAATGCAGCATGGCCTCGTGTCTGAGGACTTTGAAAGGCAGI Blood/Ram 11TTCAGCAACTGCAAACAGTAGCAATGCAGCATGGCCTCGTGTCTGAGGACTTTGAAAGGCAG] Milk/Ewe 04 TTCCAGCAACTGCAAACA GTAGCAATGCAGCATGGCCTCGTGTCCGAGGACTTTGAAAGGCAGI Blood/Ewe 04 TTCCAGCAACTGCAAACAGTAGCAATGCAGCATGGCCTCGTGTCCGAGGACTTTGAAAGGCAG] Milk/Ewe 07 TTCCAGCAACTGCAAACAGTAGCAATGCAGCATGGCCTCGTGTCCGAGGACTTTGAAAGGCAGI Blood/Ewe 07 TTCCAGCAACTGCAAACA GTAGCAATGCAGCATGGCCTCGTGTCTGAGGACTTTGAAAGGCAG] BR/CNPC-G1 TTCCAGCAACTGCAAACAGTAGCAATGCAGCATGGCCTCGTGTCTGAGGACTTTGAAAGGCAGI CAEV-Cork TTCCAGCAACTGCAAACA GTAGCAATGCAGCATGGCCTCGTGTCTGAGGACTTTGAAAGGAG]

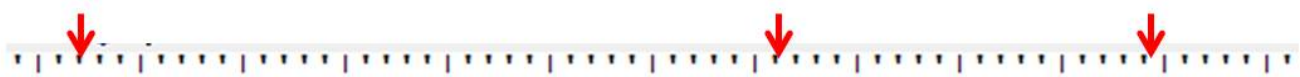

$$
\begin{aligned}
& \begin{array}{llllll}
550 & 560 & 570 & 580 & 590 & 600
\end{array}
\end{aligned}
$$

Semen/Ram 13 GTTGGCATATTATGCTACTACCTGGACAAGTAAAGACATACTAGAAGTATTGGCCATGATGCC Blood/Ram 11 GTTGGCATATTATGCTACTACCTGGACAAGTAAAGACATACTAGAAGTATTGGCCATGATGCC Milk/Ewe 04 GTTAGCATATTATGCTACTACCTGGACAAGTAAAGACATACTAGAAGTATTGGCCATGATGCC Blood/Ewe 04 GTTA GCATATTATGCTACTACCTGGACAAGTAAAGACATACTAGAAGTATTGGCCATGATGCC Milk/Ewe 07 GTTAGCATATTATGCTACTACCTGGACAAGTAAAGACCTACTAGAAGTATTGGCCCTGATGCC Blood/Ewe 07 GTTGGCATATTATGCTACTACCTGGACAAGTAAAGACATACTAGAAGTATTGGCCATGATGCC BR/CNPC-G1 GTTGGCATATTATGCTACTACCTGGACAAGTAAAGACATACTAGAAGTATTGGCCATGATGCC

CAEV-Cork GTTGGCATATTATGCTACTACCTGGACAAGTAAAGACATACTAGAAGTATTGGCCATGATGCC

* Red arrow indicates change of nucleotid in relation to the genomic sequence of the standard CAEV Corkstrain.

Figure 1. Partial sequences of the small ruminant lentivirus gag gene: results obtained from nested PCR in milk from ewes and semen from rams infected with caprine lentivirus.

Comparison of fragments obtained provides important information regarding the modified nucleic sites, and these alterations may be associated with mutations that would lead to the adaptation of the viral strain to the host. However, this experiment was not enough to attest a mutation linked to adaptation. It is emphasized that those modifications may influence the process of viral replication (Barquero et al., 2013).
Thus, there are several verified characteristics influencing lentivirus transmission, since the dissemination of the disease is not speciesspecific, and the viral quasispecies are closely linked to the evasion mechanisms of the immune response, resulting from viral RNA transcription errors by reverse transcriptase, which may be correlated with the nucleic variations observed in the present study (Pasick et al., 1998; Reina et al., 2006). 


\section{CONCLUSIONS}

Caprine lentivirus proviral DNA was detected in ewemilk and in ram-semen, in experimentally infected animals, thus suggesting the technical feasibility of infection passing from goats to sheep, despite the absence of clinical signs. The small changes observed on the genetic sequences obtained suggest that the viral strain may adapt to the new species because of the possibility of errors in gene transcription. The possibility of infection re-transmission highlights the attention that should be given to control measures of the disease in small ruminants.

\section{ACKNOWLEDGEMENTS}

The authors thank the Foundation for Research Support of the State of Bahia (Fabesp) for fostering the project, the National Council of Scientific and Technological Development $(\mathrm{CNPq})$ for funding the research. They also thank the Coordination of Higher Education Personnel Improvement (Capes) for the scholarship and Embrapa - National Research Center for Goats and Sheep for supporting the execution of the experiment.

\section{REFERENCES}

ÁlVAREZ, V.; ARRANZ, J.; DALTABUITTEST, M. et al. Relative contribution of colostrum from Maedi-Visna virus (MVV) infected ewes to MVV-seroprevalence in lambs. Res. Vet. Sci., v.78, p.237-243, 2005.

ÁlVAREZ, V.; DALTABUIT-TEST, M.; ARRANZ, J. et al. PCR detection of colostrumassociated Maedi-Visna virus (MVV) infection and relationship with ELISA-antibody status in lambs. Res. Vet. Sci., v.80, p.226-234, 2006.

ANDRIOLI, A.; GOUVEIA, A.M.G.; MARTINS, A.S. et al. Fatores de risco na transmissão do lentivírus caprino pelo sêmen. Pesqui. Agropecu. Bras., v.41, p.1313-1319, 2006.

BARBOSA, D.A.; BLAGITZ, M.G.; BATISTA, C.F. et al. Contagem automática e microscópica direta de células somáticas do leite de ovelhas Santa Inês, utilizando como corantes o Broadhurst-palley e a hematoxilina-eosina. Ciênc. Anim., v.22, p.17-23, 2012.
BARLOUGH, J.; EAST, N.; ROWE, J.D. et al. Double-nested polymerase chain reaction for detection of caprine arthritis-encephalitis virus proviral DNA in blood, milk, and tissues of infected goats. J. Virol. Methods, v.50, p.101113, 1994.

BARQUERO, N.; GOMEZ-LUCIA, E.; ARJONA, A. et al. Evolution of specific antibodies and proviral DNA in milk of small ruminants infected by small ruminant lentivirus. Viruses, v.5, p.2614-2623, 2013.

BLACKLAWS, B.A. Small ruminant lentiviruses: Immunopathogenesis of visnamaedi and caprine arthritis and encephalitis virus. Comp. Immunol. Microbiol. Infect. Dis., v.35, p.259-269, 2012.

CAVALCANTE, F.R.A., ANDRIOLI, A.; PINHEIRO, R.R. et al. Detecção do vírus da Artrite Encefalite Caprina por nested PCR e nested RT-PCR em ovócitos e fluido uterino. Arq. Inst. Biol., v.80, p.381-386, 2013.

FEITOSA， A.L.V.L.; TEIXEIRA， M.F.S.; PINHEIRO, R.R. et al. Phylogenetic analysis of small ruminant lentiviruses from northern Brazil. Small Ruminant Res., v.94, p.205-209, 2010.

GOMES, V.; AMATO, A.L.; PONTE, G.C.T.G. et al. Contagem automática e microscópica direta das células somáticas do leite de ovelhas da raça lacaune, utilizando como corantes o Rosenfeld e verde de metil e Pironina-Y. Ciênc. Anim. Bras., v.11, p.162-167, 2010.

GREGORY, L.; LARA, M.C.C.S.H.; HASEGAWA, M.Y. et al. Detecção do vírus da artrite encefalite caprina em pulmão, glândula mamária, cérebro e líquido sinovial de cabras naturalmente infectadas pela técnica de nestedPCR. Med. Vet., v.5, p.7-11, 2011.

GREGORY, L.; LARA, M.C.C.S.H.; VILLALOBOS, E.M.C. et al. Detecção do vírus da atrite encefalite caprina em amostras de leite de cabras pela reação em cadeia da polimerase (PCR) e Nested-PCR. ARS Vet., v.25, p.142-146, 2009.

GRIMBERG, J.; NOWOSCHIK, S.; BELLUSCIO, L. et al. A simple and efficient non-organic procedure for the isolation of genomic DNA from blood. Nucleic Acids Res., v.17, p.83-90, 1989. 
HALL, T.A. Bioedit: a user-friendly biological sequence alignment editor and analysis program for Windows 95/98/NT. Nucleic Acids Symposium Ser., v.41, p.95-98, 1999.

HERRMANN-HOESING, L.M.; PALMER, G.H.; KNOWLES, D.P. Evidence of proviral clearance following postpartum transmission of an ovine lentivirus. Virology, v.362, p.226-234, 2007.

PASICK, J. Maedi-visna virus and caprine arthritis-encephalitis virus: distinct species or quasispecies and its implications for laboratory diagnosis. Can. J. Vet. Res., v.62, p.241-244, 1998.

PAULA, N.R.O.; ANDRIOLI, A.; CARDOSO, J.F.S. et al. Profile of the Caprine arthritisencephalitis virus (CAEV) in blood, semen from bucks naturally and experimentally infected in the semi-arid region of Brazil. Small Ruminant Res., v.85, p.27-33, 2009.

RACHID, A.; CROISÉ, B.; RUSSO, P. et al. Diverse host-virus interactions following caprine arthritis-encephalitis virus infection in sheep and goats. J. Gen. Virol., v.94, p.634-642, 2013.

RAMÍREZ, H.; REINA, R.; BERTOLOTTI, L. et al. Study of compartmentalization in the visna clinical form of small ruminant lentivirus infection in sheep. BMC Vet. Res., v.8, p.1-12, 2012.

RAVAZZOLO, A.P.; NENCI, C.; VOGT, H.R. et al. Viral load, organ distribution, histopathological lesions and cytokine mRNA expression in goats infected with a molecular clone of the caprine arthritis encephalitis virus. Virology, v.350, p.116-127, 2006.

REINA, R.; MORA, M.I.; GLARIA, I. et al. Molecular characterization and phylogenetic study of Maedi visna and caprine arthritis encephalitis viral sequences in sheep and goats from Spain. Virus Res., v.121, p.189-198, 2006.

RIMSTAD, E.; EAST, N.E.; TORTEN, M. et al. Delayed seroconversion following naturally acquired caprine arthritis-encephalitis virus infection in goats. Am. J. Vet. Res., v.54, p.18581862, 1993.
SALTARELLI, M.; QUERAT, G.; KONINGS, D.A.M. et al. Nucleotide sequence and transcriptional analysis of molecular clones of CAEV which generate infectious virus. Virology, v.179, p.347-364, 1990.

SANTURDE, G.; SILVA, N.; VILLARES, R. et al. Rapid and high sensitivity test for direct detection of bovine herpesvirus-1 genome in clinical samples. Vet. Microbiol., v.49, p.81-92, 1996.

SARDI, S.I.; TORRES, J.A.; BRANDÃO, C.F.L. et al. Early detection of goats infected with lentivirus small ruminant virus by ELISA assay. Rev. Ciênc. Méd. Biol., v.11, p.35-40, 2012.

SHAH, C.A.; BÖNI, J.; HUDER, J.B. et al. Phylogenetic analysis and reclassification of caprine and ovine lentiviruses based on 104 new isolates: evidence for regular sheep-to-goat transmission and world-wide propagation through livestock trade. Virology, v.319, p.12-26, 2004.

SOUZA, K.C.; PINHEIRO, R.R.; SANTOS, D.O. et al. Transmission of the caprine arthritisencephalitis virus through artificial insemination. Small Ruminant Res., v.109, p.193-198, 2013.

SOUZA, T.S.; PINHEIRO, R.R.; COSTA, J.N.; et al. Interspecific transmission of small ruminant lentiviruses from goats to sheep. Braz. J. Microbiol., v.46, p.867-874, 2015.

THOMPSON, J.D; HIGGINS, D.G.; GIBSON, T.J. Clustal W: improving the sensitivity of progressive multiple sequence alignment through sequence weighting, position specific gap penalties and weight matrix choice. Nucleic Acids Res., v.22, p.4673-4680, 1994.

VILLORIA, M.; LEGINAGOIKOA, I.; LUJÁN, L. et al. Detection of small ruminant lentivirus in environmental samples of air and water. Small Ruminant Res., v.110, p.155-160, 2013. 